\title{
DAYA TERIMA DAN UJI KADAR PROTEIN PADA ES KRIM DENGAN PENAMBAHAN TEPUNG TEMPE
}

\author{
Thresia Dewi Kartini ${ }^{1}$, Nadimin ${ }^{1}$, Agung ${ }^{2}$ \\ ${ }^{1}$ Jurusan Gizi, Politeknik Kesehatan Kemenkes Makassar \\ ${ }^{2}$ Alumni Jurusan Gizi, Politeknik Kesehatan Kemenkes Makassar \\ Korespondensi : thresiadewi72@gmail.com 08242054419
}

\begin{abstract}
Ice cream is a semi-solid foods that have a high nutritional value derived from milk. Some consumers in Indonesia intolerance to milk, so milk can be used as an alternative to replace milk. The use of coconut milk in the manufacture of ice cream has not met the chemical composition so that need to add flour tempe. This study aims to determine the acceptability and analysis of protein content in ice cream with addition of flour tempe. This research is an experimental study with pre-post test design desaign group, compares the standard ice cream ice cream with the addition of soybean flour. Organoleptic research results based on the aspect of color, aroma, texture and flavor are very favored panelist is FO (concentration 0\%) with a total score of 348. The Kruskal-Wallis test results revealed that there is a difference in each formula. The results of the analysis of ice cream F1 to increase the value of protein at 4:02\% of FO at 3:06\%. It is suggested in the manufacture of ice cream with the addition of tempeh flour further to add other additives to eliminate the unpleasant aroma of tempeh and make the color becomes attractive and wearing a 80 mesh sieve.
\end{abstract}

Keywords: Acceptability, Ice cream, protein content, flour Tempe

\section{PENDAHULUAN}

Es krim adalah makanan semi padat yang terbuat dari susu, lemak, gula atau tanpa bahan tambahan lain. Beberapa fakta menyebutkan bahwa es krim memiliki nilai gizi yang tinggi tergantung pada kualitas bahan bakunya sehingga bahan baku yang digunakan perlu diketahui dengan pasti (Malaka, 2010).

Umumnya es krim mempunyai nilai gizi yang tinggi terutama protein dan lemak kerena bahan utama adalah susu. Protein dan lemak adalah zat gizi yang di butuhkan oleh semua usia. Selain kandungan gizi, faktor yang berpengaruh pada tingkat kesukaan konsumen terhadap es krim adalah cita rasa es krim. Penggunaan susu dalam pembuatan es krim tidak diinginkan oleh beberapa konsumen di Indonesia terutama yang tidak tahan laktosa, disamping adanya bau amis dari susu segar, harganya juga mahal. Masalah penggunaan susu pada produk es krim dapat diganti dengan santan sebagai alternatif terbaik, disamping menghilangkan bau amis, harganya murah dan tidak mengandung laktosa (Wijana, dkk, 2001).

Umumnya santan kelapa digunakan untuk bahan campuran makanan termasuk dalam pembuatan es krim. Komposisi kimia yang menyusun es krim adalah kadar lemak dan kadar protein. Santan mempunyai kadar lemak yang tinggi, kadar lemak menjadikan es krim lembut dan berkualitas. Disamping itu, penggunaan 
santan dapat memberikan cita rasa dan aroma yang khas pada produk es krim. Akan tetapi penggunaan santan dalam pembuatan es krim hanya memiliki kandungan lemak, sehingga perlu ditambahkan protein untuk memenuhi komposisi kimia yang menyusun es krim. Tempe dapat dijadikan alternatif untuk memenuhi komposisi kimia yang menyusun es krim (Rachman, 2016).

Tempe merupakan sumber protein nabati yang cukup tinggi dan mempunyai harga yang terjangkau. Tempe juga salah satu makanan tradisional yang telah dikenal di Indonesia, dibuat dengan cara fermentasi atau peragian. Setiap 100 gram tempe mengandung protein 20,8 gram, lemak 8,8 gram, serat 1,4 gram, kalsium $155 \mathrm{mg}$, fosfor $326 \mathrm{mg}$, zat besi $4 \mathrm{mg}$, vitamin B1 0,19 mg, dan karoten 34 ug.

Tempe mempunyai daya simpan yang singkat dan akan segera membusuk selama penyimpanan. Hal ini disebabkan oleh proses fermentasi lanjut, menyebabkan degradasi protein lebih lanjut sehingga terbentuk amoniak. Amoniak yang terbentuk menyebabkan munculnya aroma busuk (Bastian, dkk, 2013). Penanganan yang dapat dilakukan untuk memperpanjang masa simpan tempe, salah satunya mengolah tempe menjadi tepung tempe.

Tepung tempe merupakan salah satu bahan yang dapat ditambahkan untuk pembuatan es krim. Penambahan tepung tempe pada es krim dapat meningkatkan nilai gizi terutama protein. Tepung tempe 100 gram mengandung energi 692,7 kkal, protein 44,41 g, lemak 30,0 g, karbohidrat 61,47, dan Fe 8,98 mg (Lestari,dkk, 2012).

Hasil penelitian tentang optimasi penambahan buah alpukat pada es krim santan kelapa diperoleh hasil perlakuan penambahan buah alpukat sebanyak $20 \%$ dan aroma pandan sebanyak $0,2 \%$ merupakan perlakuan terbaik dalam produksi es krim santan, karakteristik es krim santan yang dihasilkan adalah kadar air $36,33 \%$, protein $1,6 \%$, lemak $23,53 \%$, overrum $37,17 \%$, kecepatan pelelehan $62,62 \%$ menit, nilai rasa 5,35, warna 5,75, aroma 5,65 dan tekstur 5,65 (Wijana, dkk, 2001).

Hasil penelitian tentang daya terima dan nilai gizi es krim dengan penambahan tepung rebung diperoleh hasil daya terima penelis terbaik yaitu formula 2. Ditinjau dari aspek rasa sebanyak $80 \%$, dari warna sebanyak $93,4 \%$, dari aspek tekstur $85,8 \%$, dan dari aspek aroma 88,6\% (Dahlan, 2017).

Uraian di atas membuat peneliti mengolah es krim berbahan dasar santan yang ditambahkan tepung tempe untuk meningkatkan kandungan protein dalam es krim. Penelitian ini bertujuan untuk mengetahui daya terima kesukaan panelis terhadap karakteristik sensoris (warna, tekstur, aroma dan rasa) dengan substitusi tepung tempe $0 \%, 5 \%, 10 \%$ dan $15 \%$ serta mengetahui karakteristik kimia (kadar protein) pada es krim dengan substitusi tepung tempe.

\section{METODE}

\section{Desain, tempat dan waktu}

Penelitian ini merupakan penelitian laboratorium, yang dilaksanakan di Laboratorium Ilmu Teknologi Pangan Jurusan Gizi Poltekkes Kemenkes Makassar dan Laboratorium Kimia, Analisa dan Pengawasan Mutu Pangan Fakultas Peternakan Universitas Hasanuddin. .

\section{Bahan dan alat}

Bahan yang digunakan dalam penelitian ini adalah santan, tepung tempe, air, tepung maizena, gula pasir, whipped cream, garam. Peralatan penelitian yang digunakan adalah oven, blender, talenan, loyang, baskom, ayakan ukuran 60 mesh, kompor, wajan, sutil besi, panci kukusan, baskom, sendok, pisau, timbangan digital, Mixer,Freezer, dan blender.

\section{Jenis dan cara pengumpulan data}

1. Jenis Data 
a. Daya terima yang diperoleh dari formulir yang diisi oleh panelis. Formulir berisi 4 aspek penilaian yaitu warna, tekstur, aroma dan rasa.

b. Peneliti menghitung nilai gizi protein yang terkandung dalam es krim dengan penambahan tepung tempe.

2. Cara pengumpulan data

a. Daya terima diperoleh dari dari formulir yang diisi oleh panelis tidak terlatih Sebanyak 25 orang. Penilaian ini menggunakan skala hedonik.

b. Nilai gizi es krim diperoleh dari hasil uji kadar protein yang dilakukan oleh peneliti.

3. Cara penilaian

a. Panelis diberi form penilaian yang harus diisi sesuai dengan keterangan pada form pada masing-masing aspek yaitu aspek warna, tekstur, aroma dan rasa.

b. Penentuan uji kadar protein dengan metode micro kjeldahl.

\section{Pengolahan dan analisis data}

Data dikelompokkan dan diolah dengan menggunakan komputer. Data hasil uji organoleptik yaitu uji hedonik (uji kesukaan) ditabulasi dalam bentuk tabel kemudian dianalisis menggunakan uji Kruskal Wallis dengan uji lanjut MannWhitney. Data yang telah dianalisis disajikan dalam bentuk tabel dan grafik disertai narasi.

\section{HASIL}

Daya Terima Es Krim dengan Penambahan Tepung Tempe

Hasil uji organoleptik yang dilakukan di Kampus Jurusan Gizi dengan jumlah penelis 25 orang yang merupakan mahasiswa Jurusan Gizi Poltekkes Kemenkes Makassar tingkat II sampai tingkat IV. Penyajian dalam penelitian ini menggunakan uji organoleptik 2 kelompok yaitu suka (sangat suka dan suka) dan tidak suka (tidak suka dan sangat tidak suka) dan didapatkan data sebagai berikut :

Daya terima terhadap aspek warna

Daya terima panelis terhadap aspek warna es krim melibatkan indera penglihatan dengan menggunakan mata. Data yang diperoleh dapat dilihat pada tabel 01 berikut.

Tabel 1.

Distribusi Daya Terima Terhadap Aspek Warna Es Krim dengan Penambahan Tepung

Tempe

\begin{tabular}{|c|c|c|c|c|c|c|c|}
\hline \multirow{3}{*}{ Formula } & \multicolumn{4}{|c|}{$\begin{array}{c}\text { Tingkat Kesukaan } \\
\text { Aspek Warna }\end{array}$} & \multirow{2}{*}{\multicolumn{2}{|c|}{ Total }} & \multirow{3}{*}{$\mathrm{p}$} \\
\hline & \multicolumn{2}{|c|}{ Suka } & \multicolumn{2}{|c|}{$\begin{array}{l}\text { Tidak } \\
\text { Suka } \\
\end{array}$} & & & \\
\hline & $\mathrm{n}$ & $\%$ & $\mathrm{n}$ & $\%$ & $\mathrm{n}$ & $\%$ & \\
\hline F0 & 24 & 96 & 1 & 4 & 25 & 100 & \multirow{4}{*}{0,001} \\
\hline $\mathrm{F} 1$ & 23 & 92 & 2 & 8 & 25 & 100 & \\
\hline $\mathrm{F} 2$ & 20 & 80 & 5 & 20 & 25 & 100 & \\
\hline $\mathrm{F} 3$ & 15 & 60 & 10 & 40 & 25 & 100 & \\
\hline
\end{tabular}

F0 : Es krim tanpa penambahan tepung tempe

$\mathrm{F} 1$ : Es krim dengan penambahan tepung tempe 5\%

F2 : Es krim dengan penambahan tepung tempe $10 \%$

$\mathrm{F} 3$ : Es krim dengan penambahan tepung tempe $15 \%$ 
Tabel 01 menunjukkan penilaian panelis terhadap daya terima es krim dari aspek warna yang paling banyak disukai adalah es krim F0 (konsentrasi 0\%) sebanyak 24 orang panelis $(96 \%)$ dan terdapat 1 panelis yang tidak suka $(4 \%)$.

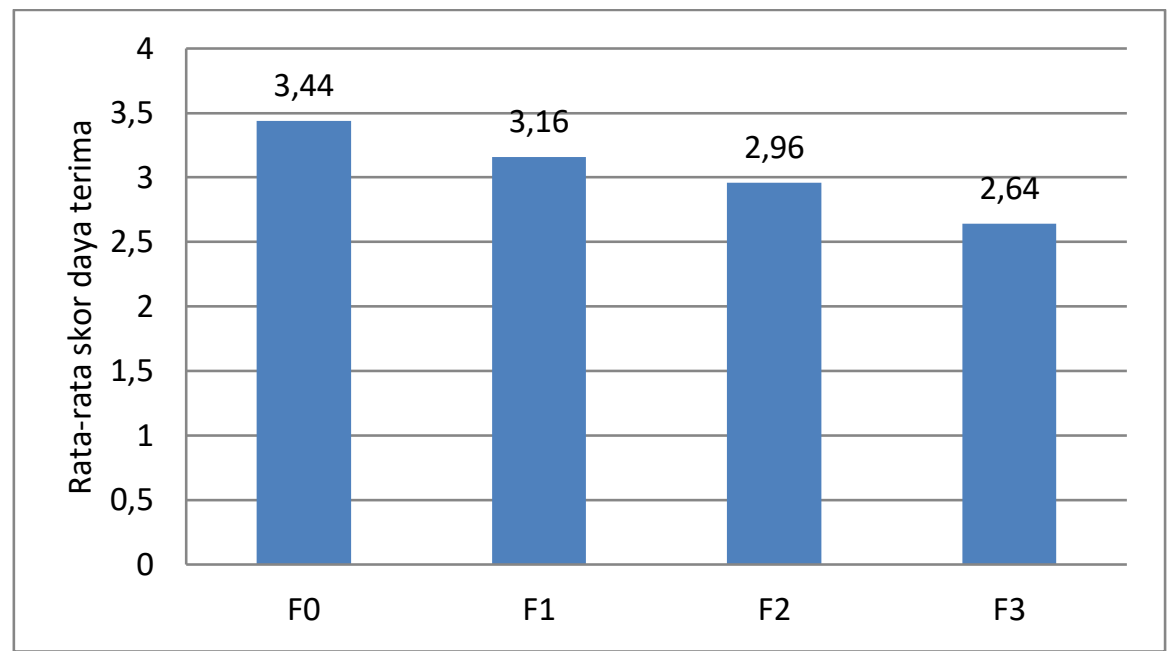

Gambar 1. Rerata Daya Terima Es Krim pada Aspek Warna dengan Penambahan Tepung Tempe

Rata-rata skor daya terima panelis terhadap aspek warna disajikan pada gambar 1 menunjukkan bahwa terdapat perbedaan pada setiap konsentrasi. Hasil uji Kruskal Wallis menunjukkan ada perbedaan daya terima terhadap aspek warna es krim dengan penambahan tepung tempe $(\mathrm{p}=0,001)$. Uji lanjut MannWhitney, formula yang menunjukkan perbedaan adalah F0 dengan F2, F0 dengan F3 dan F1 dengan F3.

Tabel 02.

Distribusi Daya Terima Terhadap Aspek Aroma Es Krim dengan Penambahan Tepung Tempe

\begin{tabular}{cccccccc}
\hline & \multicolumn{9}{c}{ Tingkat Kesukaan } \\
Aspek Aroma & \multirow{2}{*}{ Total } & \\
\cline { 2 - 5 } Formula & \multicolumn{2}{c}{ Suka } & \multicolumn{2}{c}{ Tidak } & & \\
& \multicolumn{2}{c}{ Suka } & & & \\
\cline { 2 - 6 } & $\mathrm{n}$ & $\%$ & $\mathrm{n}$ & $\%$ & $\mathrm{n}$ & $\%$ & \\
\hline F0 & 22 & 88 & 3 & 12 & 25 & 100 & \\
F1 & 21 & 84 & 4 & 16 & 25 & 100 & 0,001 \\
F2 & 19 & 76 & 6 & 24 & 25 & 100 & \\
F3 & 14 & 56 & 11 & 44 & 25 & 100 & \\
\hline
\end{tabular}

F0 : Es krim tanpa penambahan tepung tempe

F1 : Es krim dengan penambahan tepung tempe 5\% 
F2 : Es krim dengan penambahan tepung tempe $10 \%$

F3 : Es krim dengan penambahan tepung tempe $15 \%$

Rata-rata skor daya terima panelis terhadap aspek aroma disajikan pada gambar 2 menunjukkan bahwa terdapat perbedaan pada setiap konsentrasi. Hasil uji Kruskal Wallis menunjukkan ada perbedaan daya terima terhadap aspek aroma es krim dengan penambahan tepung tempe $\quad(\mathrm{p}=0,001)$. Uji lanjut MannWhitney, formula yang menunjukkan perbedaan adalah F0 dengan F1, F0 dengan F2 dan F0 dengan F3

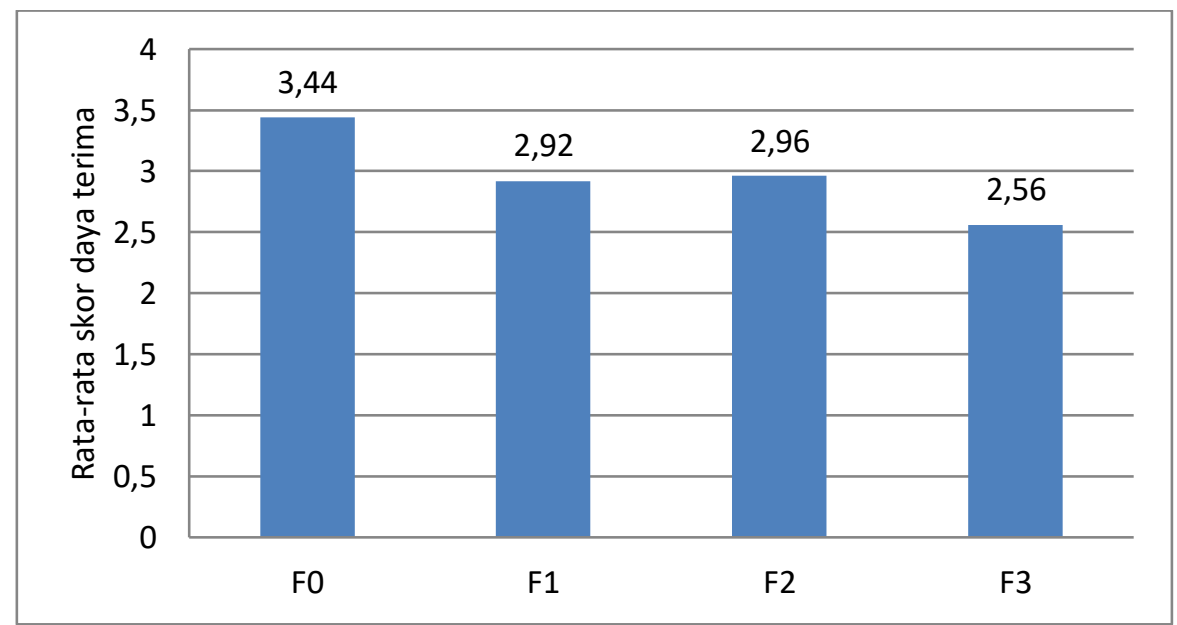

Gambar 2. Rerata Daya Terima Es Krim pada Aspek Aroma dengan Penambahan Tepung Tempe

Daya terima terhadap aspek tekstur

Daya terima panelis terhadap aspek penglihatan dan pengecap. Data yang diperoleh dapat dilihat pada tabel 03 berikut.

tekstur es krim melibatkan indera

Tabel 03.

Distribusi Daya Terima Terhadap Aspek Tekstur Es krim dengan Penambahan Tepung Tempe

\begin{tabular}{|c|c|c|c|c|c|c|c|}
\hline \multirow{3}{*}{ Formula } & \multicolumn{4}{|c|}{$\begin{array}{c}\text { Tingkat Kesukaan Aspek } \\
\text { Tekstur }\end{array}$} & \multirow{2}{*}{\multicolumn{2}{|c|}{ Total }} & \multirow{3}{*}{$\mathrm{p}$} \\
\hline & \multicolumn{2}{|c|}{ Suka } & \multicolumn{2}{|c|}{$\begin{array}{l}\text { Tidak } \\
\text { Suka }\end{array}$} & & & \\
\hline & $\mathrm{n}$ & $\%$ & $\mathrm{n}$ & $\%$ & $\mathrm{n}$ & $\%$ & \\
\hline F0 & 25 & 100 & 0 & 0 & 25 & 100 & \multirow{4}{*}{0,000} \\
\hline $\mathrm{F} 1$ & 20 & 80 & 5 & 20 & 25 & 100 & \\
\hline $\mathrm{F} 2$ & 18 & 72 & 7 & 28 & 25 & 100 & \\
\hline $\mathrm{F} 3$ & 15 & 60 & 10 & 40 & 25 & 100 & \\
\hline
\end{tabular}

Sumber : Data Primer, 2019

F0 : Es krim tanpa penambahan tepung tempe

$\mathrm{F} 1$ : Es krim dengan penambahan tepung tempe 5\%

F2 : Es krim dengan penambahan tepung tempe $10 \%$

F3 : Es krim dengan penambahan tepung tempe $15 \%$ 
Tabel 03 menunjukkan penilaian panelis terhadap daya terima es krim dari aspek tekstur yang paling banyak disukai adalah es krim F0 (konsentrasi 0\%) sebanyak 25 orang panelis $(100 \%)$.

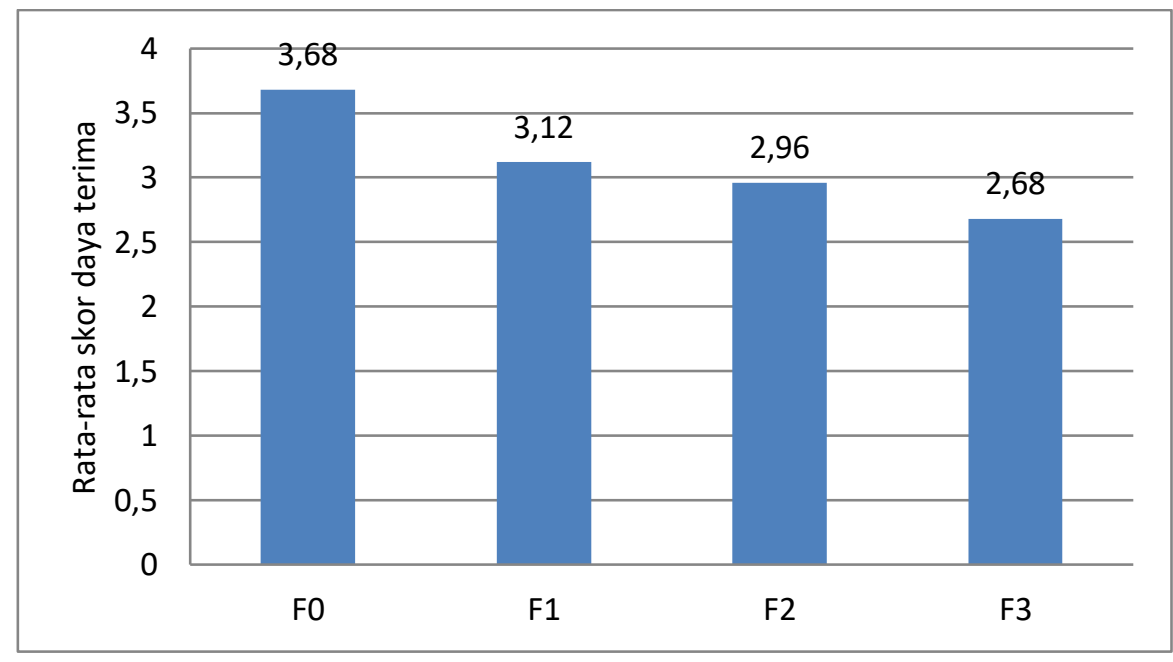

Gambar 3. Rerata Daya Terima Es Krim pada Aspek Tekstur dengan Penambahan Tepung Tempe

Rata-rata skor daya terima panelis terhadap aspek tekstur disajikan pada gambar 3 menunjukkan bahwa terdapat perbedaan pada setiap konsentrasi. Hasil uji Kruskal Wallis menunjukkan ada perbedaan daya terima terhadap aspek tekstur es krim dengan penambahan tepung tempe $(\mathrm{p}=0,000)$. Uji lanjut MannWhitney, formula yang menunjukkan

Tabel 04.

Distribusi Daya Terima Terhadap Aspek Rasa Es krim dengan Penambahan Tepung Tempe

\begin{tabular}{cccccccc}
\hline \hline & \multicolumn{3}{c}{ Tingkat Kesukaan } \\
Aspek Rasa & \multirow{2}{*}{ Total } & \\
\cline { 2 - 5 } Formula & \multicolumn{2}{c}{ Suka } & \multicolumn{2}{c}{ Tidak } & & \\
& \multicolumn{2}{c}{ Suka } & & & \\
\cline { 2 - 6 } & $\mathrm{n}$ & $\%$ & $\mathrm{n}$ & $\%$ & $\mathrm{n}$ & $\%$ & \\
\hline F0 & 22 & 88 & 3 & 12 & 25 & 100 & \\
F1 & 19 & 76 & 6 & 24 & 25 & 100 & \multirow{2}{*}{0,000} \\
F2 & 13 & 52 & 12 & 48 & 25 & 100 & \\
F3 & 10 & 40 & 15 & 60 & 25 & 100 & \\
\hline
\end{tabular}

Sumber : Data Primer, 2019

F0 : Es krim tanpa penambahan tepung tempe

$\mathrm{F} 1$ : Es krim dengan penambahan tepung tempe $5 \%$

F2 : Es krim dengan penambahan tepung tempe $10 \%$

$\mathrm{F} 3$ : Es krim dengan penambahan tepung tempe $15 \%$ 
Tabel 04 menunjukkan penilaian panelis terhadap daya terima es krim dari aspek warna yang paling banyak disukai adalah es krim F0 (konsentrasi 0\%) sebanyak 22 orang panelis $(88 \%)$ dan terdapat 3 panelis yang tidak suka (12\%).

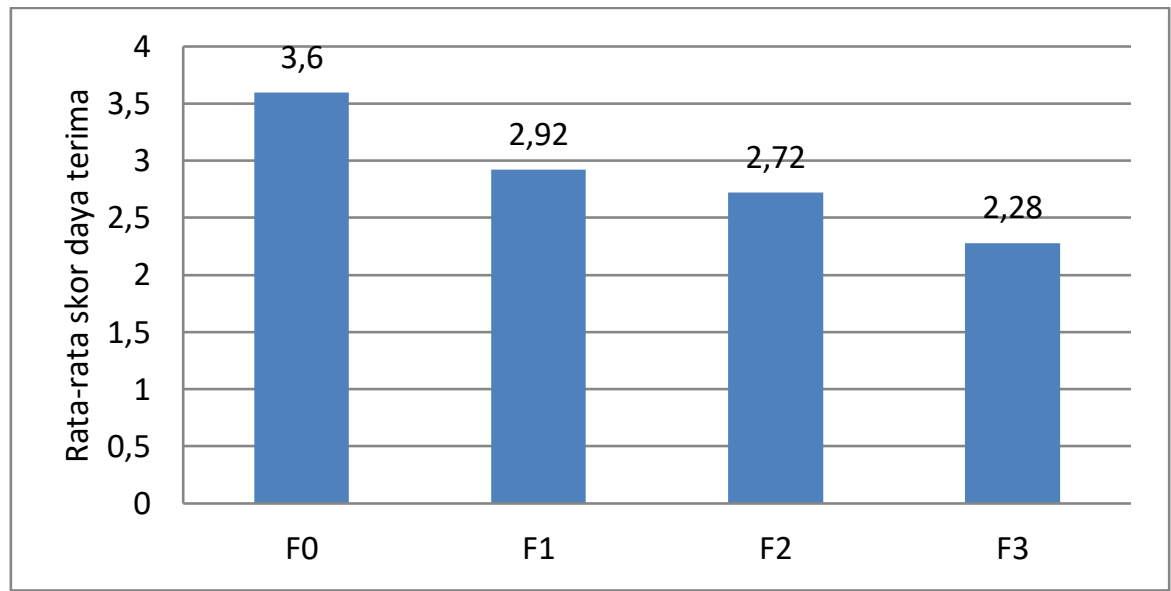

Gambar 4. Rerata Daya Terima Es Krim pada Aspek Rasa dengan Penambahan Tepung Tempe

Rata-rata skor daya terima panelis terhadap aspek tekstur disajikan pada gambar 4 menunjukkan bahwa terdapat perbedaan pada setiap konsentrasi. Hasil uji Kruskal Wallis menunjukkan ada perbedaan daya terima terhadap aspek rasa es krim dengan penambahan tepung tempe ( $\mathrm{p}=0,000)$. Uji lanjut Mann-Whitney, konsentrasi yang menunjukkan perbedaan adalah F0 dengan F1, F0 dengan F2, F0 dengan F3 dan F1 dengan F3.

Tabel 05.

Rerata Skor Aspek Penilaian Daya Terima Panelis terhadap Es Krim dengan Penambahan Tepung Tempe

\begin{tabular}{cccccc}
\hline \hline Formula & Warna & Aroma & Tekstur & Rasa & Rata-rata \\
\hline F0 & 65,22 & 67,40 & 70,02 & 72,70 & 68,83 \\
F1 & 53,92 & 48,74 & 49,88 & 51,50 & 51,01 \\
F2 & 46,26 & 49,34 & 42,32 & 44,54 & 45,61 \\
F3 & 36,60 & 36,52 & 37,78 & 32,26 & 35,79 \\
Nilai p & 0,001 & 0,001 & 0,000 & 0,000 & \\
\hline
\end{tabular}

Tabel 05 hasil skor daya terima panelis terhadap 4 aspek yaitu warna, aroma, tekstur dan rasa dapat dilihat bahwa rata-rata skor es krim F0 tertinggi yaitu 68,83 . Hasil dapat disimpulkan bahwa yang paling banyak disukai panelis baik dari aspek warna, aroma, tekstur dan rasa yaitu pada es krim konsentrasi $0 \%$ artinya adanya penambahan tepung tempe semakin tinggi pada produk es krim santan, maka semakin rendah daya terima panelis. Namun kadar zat gizi yaitu protein pada F0 lebih rendah dibandingkan dengan F1 yakni es krim yang terdapat penambahan tepung tempe. Hasil uji kruskal wallis menunjukkan terdapat perbedaan yang signifikan $(p<0,05)$ pada daya terima es krim dengan penambahan tepung tempe terhadap aspek warna, aroma, tekstur dan rasa. 
Hasil uji kadar protein

Analisa : Kadar protein

Metode : Mikro kjedhall dengan alat Kjell Master merk Buchi.

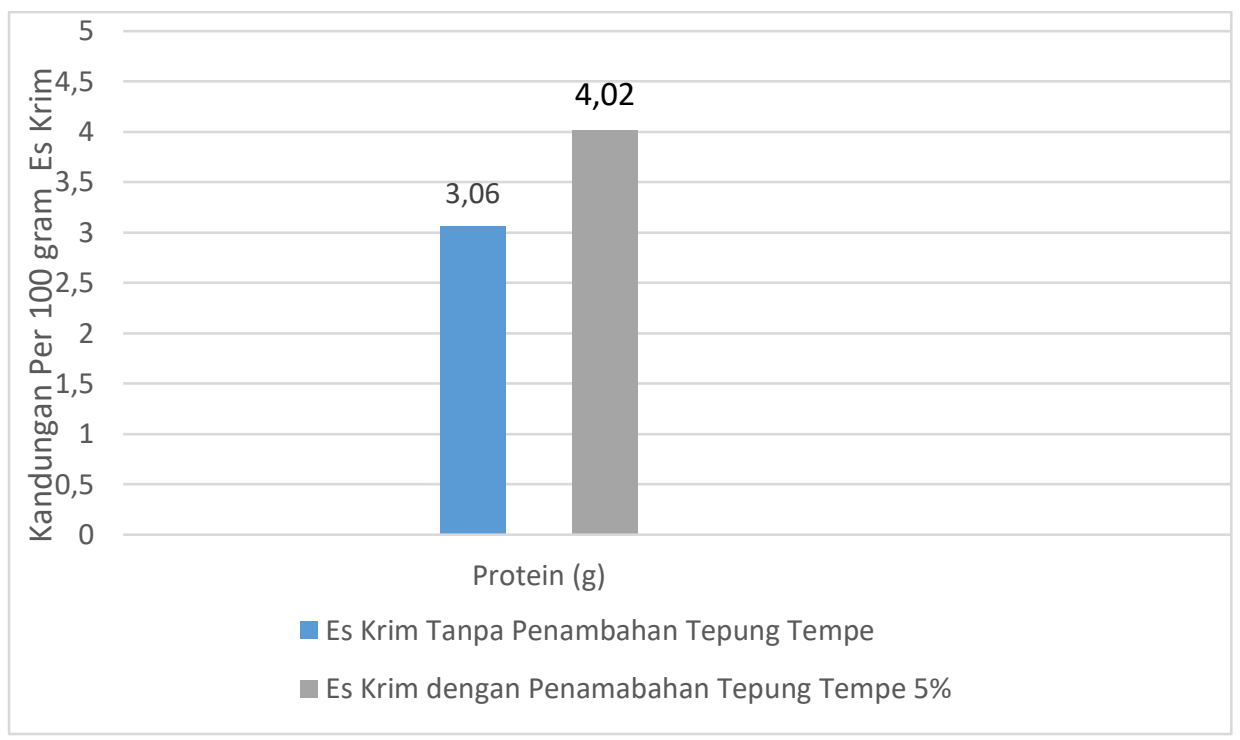

Gambar 5. Nilai Gizi Es Krim dengan Penambahan Tepung Tempe

Gambar 5 menunjukkan hasil kandungan protein es krim terjadi peningkatan dari 3,06\% menjadi $4,02 \%$. Peningkatan ini terjadi setelah ditambahkan tepung tempe sebesar 5\%.

\section{PEMBAHASAN}

Warna merupakan salah satu faktor yang sangat penting dalam penerimaan atau penolakan suatu produk karena kesan pertama yang dilihat panelis (Fitri, ddk, 2017). Warna merupakan hal yang pertama kali mempengaruhi seseorang untuk menentukan suka atau tidak suka terhadap produk tersebut.

Hasil penilaian uji organoleptik, menunjukkan bahwa warna es krim setiap konsetrasi terdapat perbedaan. Tingkat kesukaan warna pada es krim F0 menunjukkan nilai yang lebih tinggi dari pada es krim F1, F2 dan F3. Hasil uji Mann-Whitney F0 dengan F1 tidak memberikan perbedaan yang signifikan terhadap daya terima panelis. Hal ini disebabkan penambahan tepung tempe pada $\mathrm{F} 1$ hanya 5\% sehingga masih sulit dibedakan dengan F0. Berbeda dengan F2 dan F3 yang semakin banyak penambahan tepung tempe dalam es krim maka daya terima panelis menjadi menurun. Kondisi ini karena penambahan tepung tempe yang semakin banyak membuat warna es krim menjadi kurang menarik, sehingga mempengaruhi daya terima panelis. Hasil uji statistik diperoleh, $\mathrm{P}<(0,05)$ artinya terdapat perbedaan pada setiap Formula.

Sejalan dengan penelitian Ramadhani (2017), menunjukkan bahawa berdasarkan hasil daya terima terhadap aspek warna, es krim original disukai oleh panelis sebanyak 68\%, karena menghasilkan es krim yang berwarna putih bersih kerena tidak ada penambahan buah naga merah. Tidak sejalan dengan penelitian Umela (2016) menyatakan bahwa berdasarkan hasil daya terima terhadap aspek warna yang sangat disukai panelis adalah es krim dengan penambahan kacang hijau dengan konsentrasi tinggi.

Aroma adalah bau yang ditimbulkan oleh rangsangan kimia yang tercium oleh syaraf-syaraf olfakori yang berbeda dalam rongga hidung ketika makanan masuk ke dalam mulut (Winarno, 
2004). Hasil penelitian uji organoleptik menunjukan bahwa tingkat kesukaan panelis untuk aspek aroma yang paling disukai panelis adalah F0 dari pada es krim F1, F2 dan F3. Hal ini disebabkan F0 mempunyai aroma khas yang berasal dari bahan dasarnya yaitu santan dan whipped cream. Berbeda dengan F1, F2 dan F3 yang ditambahkan tepung tempe dalam es krim maka daya terima panelis menjadi menurun, karena tepung tempe memiliki aroma khas tempe (aroma langu), sehingga mempengaruhi daya terima panelis. Hasil uji statistik diperoleh, $\mathrm{P}<$ $(0,05)$ artinya terdapat perbedaan pada setiap Formula.

Sejalan dengan penelitian Windasari (2018), menunjukkan bahwa tingkat kesukaan tertinggi pada aspek aroma adalah konsentrasi $25 \%$ dengan jumlah 28 panelis (93\%). Sedangkan tingkat kesukaan terendah adalah konsentrasi 75\% dengan jumlah 17 panelis $(57 \%)$. Hal ini menunjukkan bahwa semakin tinggi konsentrasi penambahan tepung ubi jalar ungu dan tepung tempe semakin rendah pula daya terimanya. Tidak sejalan dengan penelitian Simanungkalit, dkk (2016) menunjukkan bahwa semakin tinggi konsentrasi panambahan kacang merah semakn tinggi pula daya terimanya dari aspek aroma.

Tekstur merupakan atribut penilaian yang mempengaruhi penerimaan penelis terhadap daya terima. Tekstur bersifat kompleks dan dengan struktur bahan yang terdiri dari tiga elemen yaitu: mekanik (kekerasan, kekenyalan), geometric (berpasir, beremah) dan mouthfeel (berminyak, berair) (Setyaningsih, dkk, 2010).

Hasil penilaian uji organoleptik, menunjukkan bahwa tekstur es krim setiap konsetrasi terdapat perbedaan. Tingkat kesukaan tekstur pada es krim F0 menunjukkan nilai yang lebih tinggi dari pada es krim F1, F2 dan F3, disebabkan F0 mempunyai tekstur padat dan halus sehingga sangat disukai panelis. Berbeda dengan F1, F2 dan F3 yang ditambahkan tepung tempe dalam es krim maka daya terima panelis menjadi menurun, hal ini karena penambahan tepung tempe yang diayak menggunakan ayakan $60 \mathrm{mesh}$, sehingga masih mempengaruhi tekstur es krim secara umum. Hasil uji statistik diperoleh, $\mathrm{P}<(0,05)$ artinya terdapat perbedaan pada setiap Formula.

Penelitian ini sejalan dengan penelitian Dahlan (2017), hasil uji daya terima terhadap aspek tekstur jika dibandingkan dengan Formula 1 maka es krim yang paling banyak disukai yaitu formula 2 sebanyak $85,8 \%$. Hal ini disebabkan tepung rebung yang ditambahkan tidak terlalu banyak, sehingga tidak menghasilkan es krim dengan tekstur yang terlalu mencolok dibandingkan dengan es krim pada umumnya.

Rasa merupakan aspek penting dalam menilai suatu makanan tertentu dengan menggunakan panca indera pengecap dan merupakan hal kedua setelah penampilan makanan dalam membentuk pilihan terhadap makanan dan menilai cita rasa sebagai alasan utama untuk memilih makanan tertentu, setiap orang memiliki kepekaan berbeda-beda dalam menilai suatu produk/makanan (Follows, 2014).

Hasil penilaian uji organoleptik, menunjukkan bahwa tekstur es krim setiap konsetrasi terdapat perbedaan. Tingkat kesukaan tekstur pada es krim F0 menunjukkan nilai yang lebih tinggi dari pada es krim F1, F2 dan F3, karena F0 mempunyai mempunyai rasa yang manis tanpa ada panambahan tepung tempe. Hasil uji statistik diperoleh, $\mathrm{P}<(0,05)$ artinya terdapat perbedaan pada setiap Formula.

Sejalan dengan penelitian Emilia (2016), menunjukkan bahwa daya terima panelis berdasarkan aspek rasa pada umumnya, es krim buah dengen dengan penambahan $25 \mathrm{gr}$ terdapat $79 \%$ penelis yang menyatakan suka karena konsentrasi 
pemberian buah dengen yang tidak terlalu mencolok. Tidak sejalan dengan penelitian Sanggur (2017) mununjukkan bahwa semakin tinggi konsentrasi penambahan nanas semakin tinggi pula daya terimanya dari aspek rasa.

Secara keseluruhan dari aspek warna, aroma, tekstur dan rasa es krim dengan penambahan tepung tempe yang memiliki penerimaan paling tinggi secara berurut adalah F0, F1, F2 dan F3.

Hasil analisis kandungan protein pada es krim dengan penambahan tepung tempe menunjukkan bahwa kandungan protein es krim F1 mengalami peningkatan dibandingkan dengan es krim F0 (original), pada eskrim penambahan tepung tempe F1 meningkatkan nilai protein sebesar $4.02 \%$. Sedangkan F0 sebesar 3.06\%, Hal ini dikarenakan pada F1 terdapat penambahan tepung tempe 10 gram, sedangkan pada F0 tidak dilakukan penambahan tepung tempe. Hal ini dikarenakan kandungan gizi tepung tempe per 100 gram yaitu energi 692,7 kkal, protein 44,41 g, lemak 30,0 g, karbohidrat 61,47 g, dan $\mathrm{Fe} \quad 8,7 \mathrm{mg}$ (Lestari,dkk, 2012).

\section{KESIMPULAN}

Pembuatan es krim dengan penambahan tepung tempe menunjukkan semakin tinggi penambahan tepung tempe semakin mempengaruhi daya terima es krim dari segi warna, tekstur, aroma dan rasa. Es krim tempe dengan konsentrasi $0 \%$ merupakan produk yang paling disukai dan merupakan konsentrasi terbaik berdasarkan hasil uji Kruskal Wallis. Hasil uji Kruskal Walis menunjukkan terdapat perbedaan pada setiap konsentrasi dari aspek warna, aroma tekstur dan rasa. Nilai gizi protein yang terkandung dalam es krim F0 yaitu 3,06 \% dan F1 yaitu 4,02\%.

\section{SARAN}

Pembuatan tepung tempe sebaiknya menggunakan ayakan 80 mesh, untuk mendapatkan hasil tepung tempe yang lebih halus. Penambahan bahan lain untuk menghilangkan aroma langu tempe dan membuat warna menjadi menarik.

\section{DAFTAR PUSTAKA}

Bastian F, Ishak E, Tawali A.B, \& Bilang M. (2013). Daya Terima Dan Kandungan Zat Gizi Formula Tepung Tempe dengan Penambahan Semi Refined Carrageenan (SRC) dan Bubuk Kakao. Jurnal Aplikasi Teknologi Pangan, 1.

Dahlan, A. (2017). Daya Terima dan Nilai Gizi Es Krim Dengan Penambahan Tepung Rebung. Makassar: [Karya Tulis Ilmiah] Politeknik Kemenkesn Makassar.

Emilia. (2016). Daya Terima Masyarakat Terhadap Es Krim Buah Dengen. Kementerian Kesehatan Republik Indonesia Jurusan Gizi Politekknik Kesehatan Program Studi Diploma III Gizi Makassar.

Fellows, P.J. (2014).Teknologi Pengelolahan Pangan Prinsip dan Praktik. Jakarta. Penerbit Buku Kedokteran EGC.

Fitri, Nuraini dan Eni Purwani. (2017). Pengaruh Subtitusi Tepung Ikan Kembung (Rastrelliger Brachhysoma) Terhadap Kadar Protein Dan Daya Terima Biskuit. Prosinding Seminar. Universitas Muhammadiyah Surakarta.

Malaka. (2010). Pengantar Teknologi Susu. Makassar: Masagena Press.

Lestari, L., Prawirohartono, E., Tsalissavrina, I. (2012). Efek F100 dan Formula Tepung Tempe Terhadap Kadar Serum Fe dan Hemoglobin pada Anak Gizi Kurang. Gizi Klinik Indonesia, 2533.

Rachman, A., Koyo, A., \& Rokhayati, U. (2016). Tingkat Penggunaan Santan Kelapa dan Tepung Ubi Hutan (Dioscorea hispida dennts) pada 
Pembuatan Es Krim. Media Agrosains Vol.2 No.01, 16-24.

Ramadhani, Q. (2017). Daya Terima dan Nilai Gizi Es Krim dengan Penamabahan Buah Naga Merah. Kementerian Kesehatan Republik Indonesia Jurusan Gizi Politekknik Kesehatan Program Studi Diploma III Gizi Makassar.

Sanggur, F,Y. (2017). Kualiats Organoleptik, dan Daya Leleh Es Krim dengan Penambahan Presentasi Buah Nenas (Ananas Satifus) Berbeda. Fakultas Penernakan Universitas Hasanuddin Makassar.

Setyaningsih D, dkk. (2010). Analisis Sensori untuk Industri Pangan dan Agro. Bogor. Institut Pertanian Bogor.

Umule, S. (2016). Analisis Mutu Es Krim Kacang Hijau (Phaseolus Raditus L) dan Susu Sapi Segar. Staf Pengajar Prodi Teknologi Hasil Pertanian Politeknik Gorontalo.

Wijana, S., Effendi, U., \& Setiati, E. (2001). Optimasi Penambahan Buah Apokat Pada Es Krim Santan Kelapa. Jurnal Teknologi Pertanian, 87-91.a

Winarno. (2004). Kimia Pangan dan Gizi. Gramedia Jakarta

Windasari. (2018). Daya Terima Masyarakat dan Analisis Zat Gizi Makro Terhadap Kerupuk Keju dengan Subtitusi Tepung Ubi Ungu dan Tepung Tempe. Kementerian Kesehatan Republik Indonesia Jurusan Gizi Politekknik Kesehatan Program Studi Sarjana Terapan Gizi Makassar. 